\title{
Landscape analysis of the family planning situation in Pakistan-District profile: Multan
}

Population Council

Follow this and additional works at: https://knowledgecommons.popcouncil.org/departments_sbsr-rh

Part of the Demography, Population, and Ecology Commons, Family, Life Course, and Society Commons, and the International Public Health Commons How does access to this work benefit you? Let us know!

\section{Recommended Citation}

"Landscape analysis of the family planning situation in Pakistan-District profile: Multan." Islamabad: Population Council, 2016. 


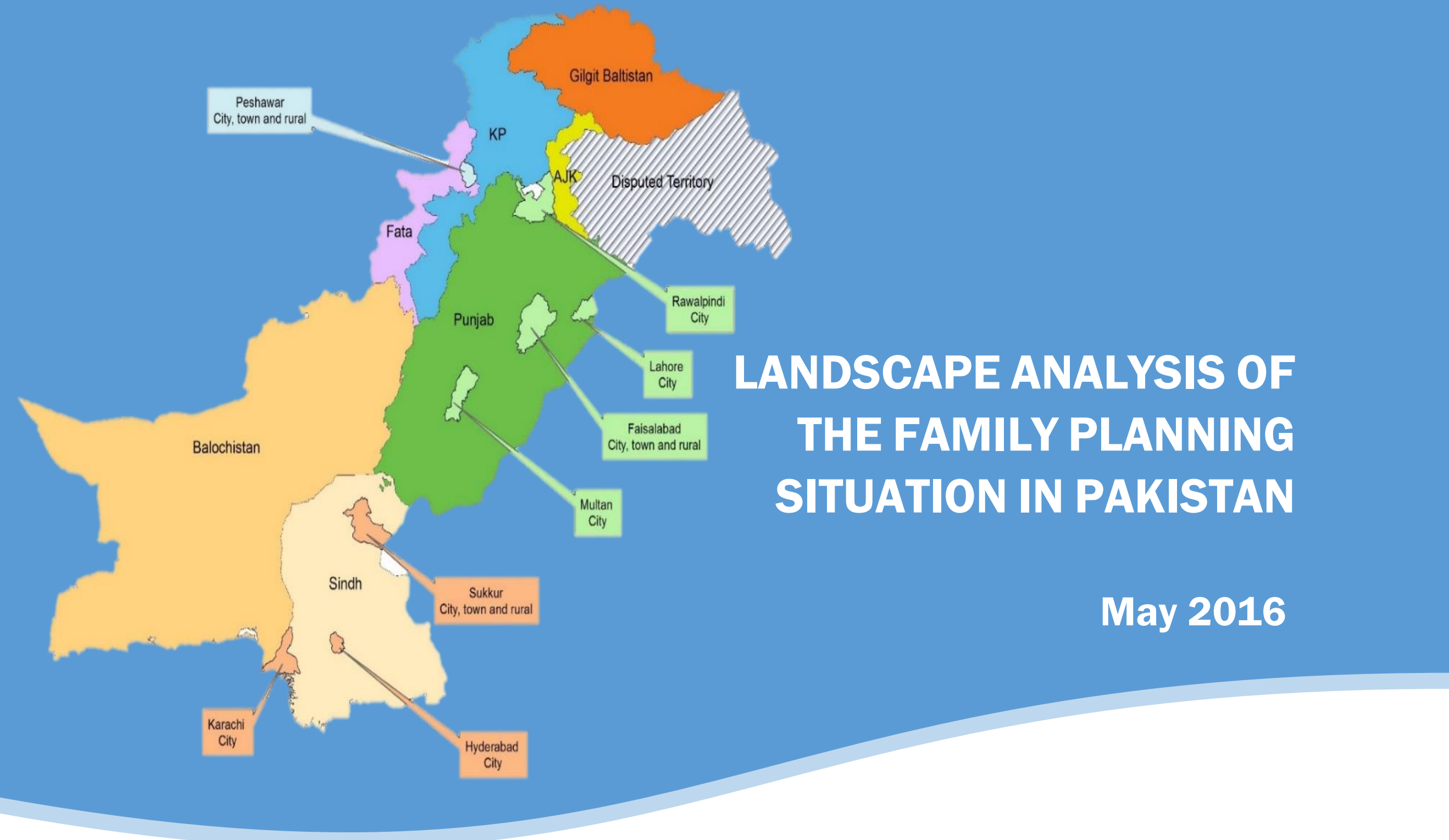

\section{DISTRICT PROFILE: MULTAN}

BILL \& MELINDA

GATES foundation

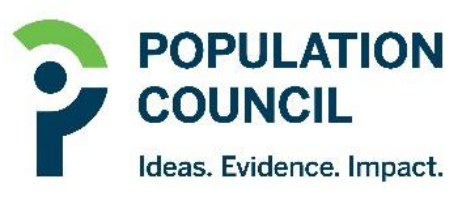




\section{Background}

Multan is located in southern Punjab. Its estimated population is 4.3 million, with a higher proportion residing in rural areas. ${ }^{1}$ The district consists of seven administrative divisions, including six towns and one cantonment area (Figure 1).

Table 1 presents basic demographic facts about the district. Of the estimated 0.7 million women of reproductive age (MWRA) in the district, 0.4 million lives in rural areas. Multan's total fertility rate (TFR) is estimated at 3.6, which is slightly above Punjab's average of 3.5.2 The infant mortality rate in the district is 71 .

\section{Table 1: Demographics of Multan}

\begin{tabular}{|c|c|c|c|}
\hline Demographics & Urban & Rural & Overall \\
\hline Total population & $1,824,000$ & $2,508,000$ & $4,332,000$ \\
\hline Women 15-49 & 489,000 & 610,000 & $1,099,000$ \\
\hline MWRA & 300,000 & 436,000 & 736,000 \\
\hline $\begin{array}{l}\text { Literacy rate (10 } \\
\text { years and above)* }\end{array}$ & $75 \%$ & $50 \%$ & $60 \%$ \\
\hline $\mathrm{IMR} * *$ & - & - & 71 \\
\hline TFR ** & - & - & 3.6 \\
\hline \multicolumn{4}{|c|}{$\begin{array}{l}\text { Source: Punjab Development Statistics 2015, * Pakistan Social and Living } \\
\text { Standards Measurement Survey (PSLMS) 2014-15, ** Multiple Indicator } \\
\text { Cluster Survey Punjab (MICS) } 2014\end{array}$} \\
\hline
\end{tabular}

\section{Figure 1: Map of Multan District}

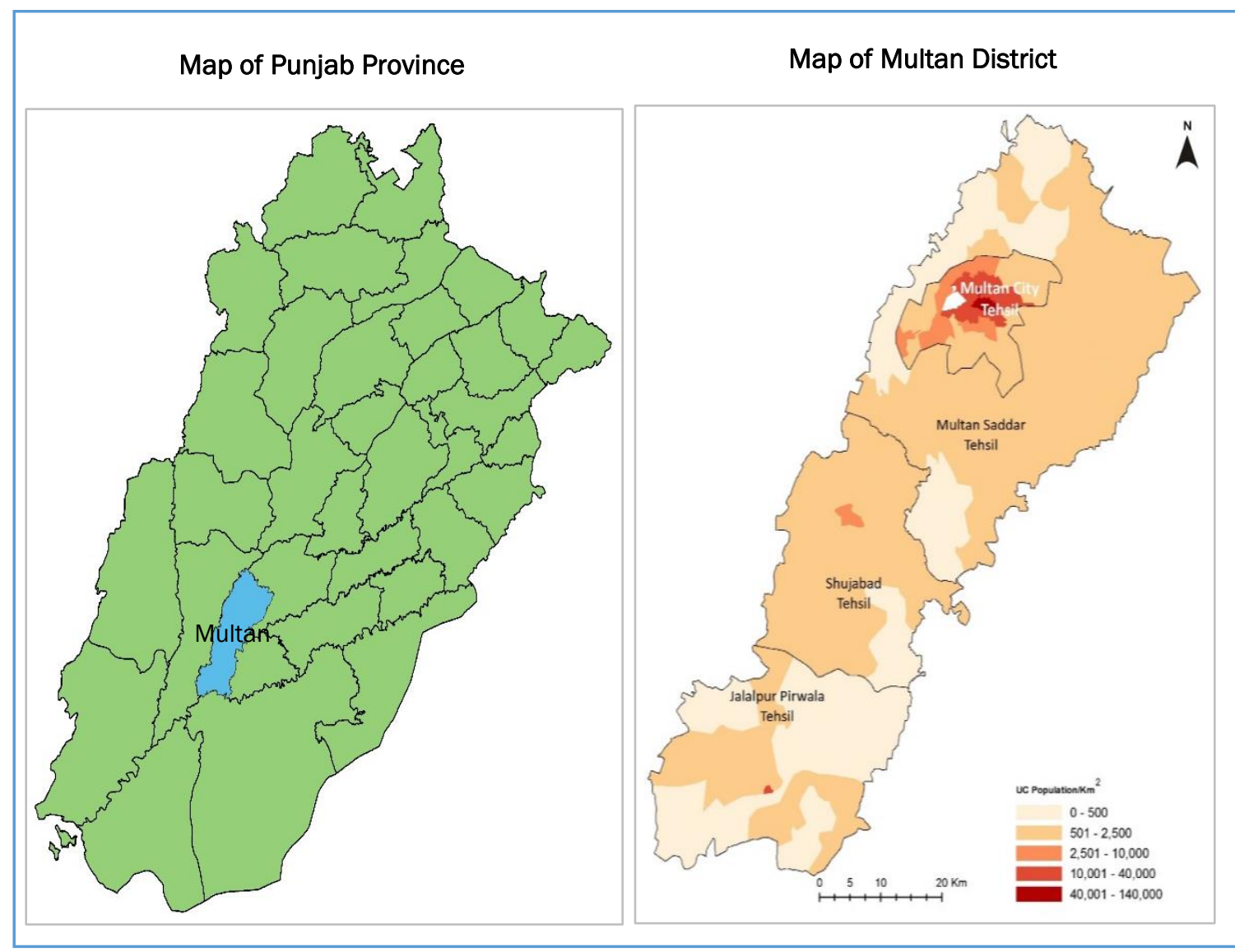

\section{Use of Antenatal and Delivery Care Services}

The majority of women in Multan sought antenatal health care from a skilled healthcare provider during their last pregnancy (70\%). ${ }^{3}$ The proportion of women who sought antenatal health care is higher in urban (79\%) than rural areas (65\%). In both urban and rural areas, the majority sought health care from a private hospital or clinic.

1 Punjab development Statistics 2015

2 Multiple Indicator Cluster Survey (MICS) Punjab 2014

3 Pakistan Social and Living Standards Measurement Survey (PSLMS) 2014-15 
The place of delivery in urban areas are most commonly private hospitals or clinics (52\%), followed by government health facilities and homes ( $24 \%$ each). However, in rural areas, more than 50 percent of deliveries take place at home.

\section{Use of Family Planning}

Among currently married women, 39 percent $^{4}$ are using any contraceptive method, with 35.2 percent using modern methods and 3.8 percent using traditional methods. Overall, the urban CPR exceeds the rural CPR by 10 percentage points. Unmet need for family planning in the district, at 16.6 percent, is less than Punjab's average of 17.5 percent.

Table 2: Contraceptive use and Unmet Need

\begin{tabular}{|c|c|c|c|c|c|}
\hline \multirow{2}{*}{ District } & & \multicolumn{3}{|c|}{ Contraceptive Prevalence Rate (CPR) } & \multirow[b]{2}{*}{$\begin{array}{l}\text { Un-met } \\
\text { need }\end{array}$} \\
\hline & & Any Method & $\begin{array}{l}\text { Traditional } \\
\text { Methods }\end{array}$ & $\begin{array}{l}\text { Modern } \\
\text { Methods }\end{array}$ & \\
\hline \multirow[t]{3}{*}{ Multan } & & 39.0 & 3.8 & 35.2 & 16.6 \\
\hline & Urban & 45.4 & 4.7 & 40.7 & 14.6 \\
\hline & Rural & 35.2 & 3.2 & 32.0 & 17.8 \\
\hline
\end{tabular}

\section{Other Soclo-economic Indicators}

The literacy rate (10 years and above) in Multan is 60 percent, but with large urban-rural differences (urban 75\%, rural 50\%). Female literacy is quite high in urban areas (72\%), but very low in rural areas (38\%).

The majority of households have a television set (63\%), but again urban-rural differences are huge, with 84 percent of urban households owning a TV set compared to only 49 percent of rural households. Mobile or land line phones are owned by the vast majority of households (91\%), both in urban (95\%) and rural areas (89\%).

In terms of house building materials, garder (iron slabs) /T-Iron roofs are used in 58 percent of houses in Multan (rural 68\%, urban 43\%); reinforced cement concrete (RCC) or reinforced bricks concrete (RBC) roofs are also popular in urban areas (41\%). Burnt bricks or blocks are the mainly used material for walls of houses in both urban (98\%) and rural areas (80\%). These indicators show, urban households have fairly good socio-economic conditions than rural households.

${ }^{4}$ Multiple Indicator Cluster Survey Punjab (MICS) 2014

\section{Avallability of Health Facilities and LHWs}

A census of public and private health facilities was carried out in Multan in 2010 under the USAID-funded Family Advancement for Life and Health (FALAH) project. Figure 2 shows the breakdown of the public and private health facilities in urban and rural areas in the district. There are more private facilities in the urban areas (75\%), and more Lady Health Workers (LHWs) in rural areas (40\%), although this cadre also makes up a good proportion of service delivery points in urban areas (22\%). Facilities of the Department of Health (DoH) are more numerous in the urban areas, while facilities of the People's Primary Healthcare Initiative (PPHI)/Punjab Rural Support Program (PRSP) are only there in the rural areas.

Figure 2: Urban-rural Distribution of Health Facilities in Multan by Sector, 2010
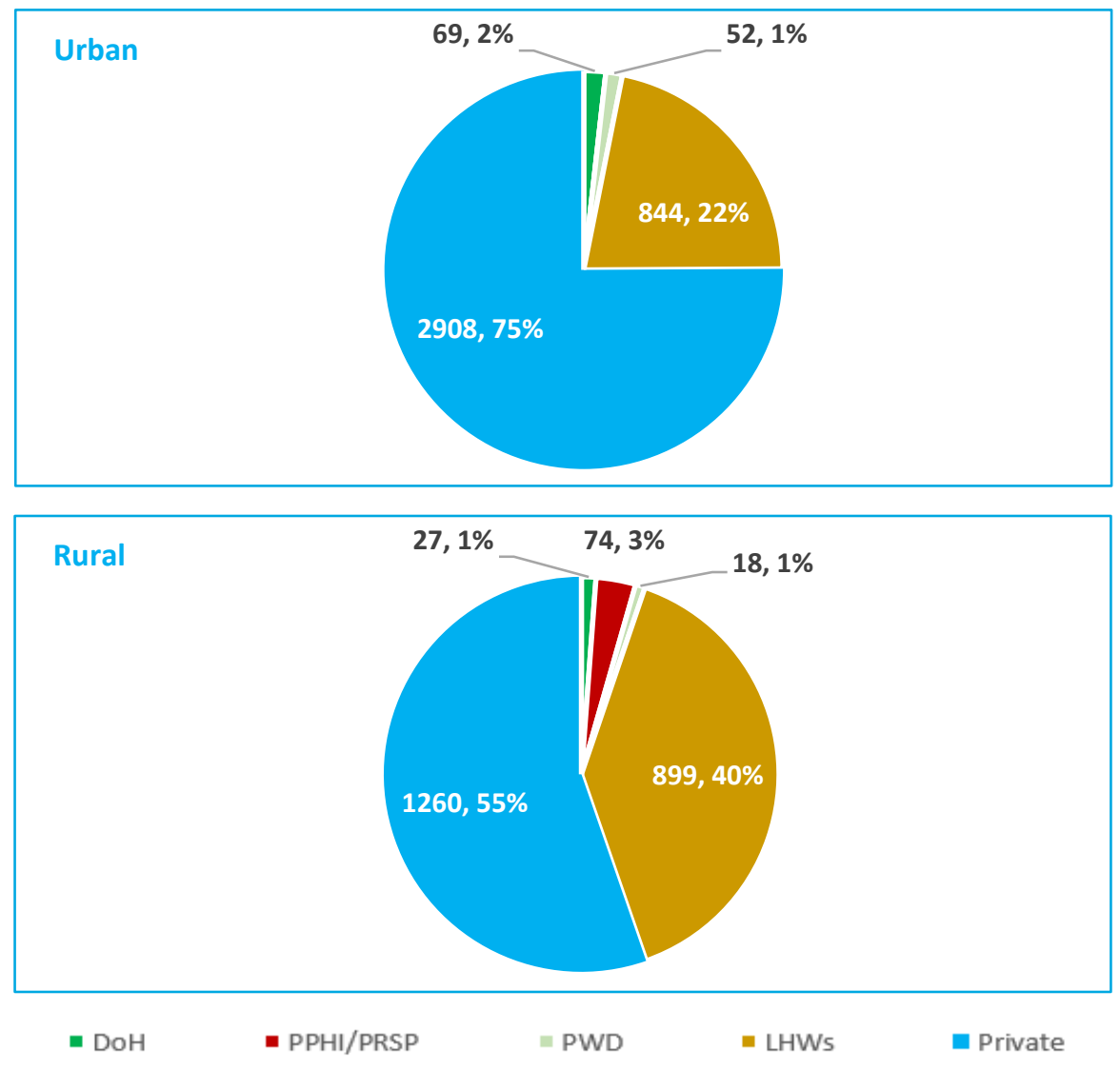


\section{Distribution of Static Public Health Facilities by Cadre}

Figure 3 shows the distribution of public facilities in urban and rural areas of Multan. In urban areas, the Family Welfare Centers (FWCs) of the Population Welfare Department (PWD) are present in larger numbers (37\%), followed by DoH's dispensaries (29\%) and $\mathrm{MCH}$ centers/maternity homes (20\%). In rural areas, facilities of PPHI/PRSP are most numerous (62\%), followed by dispensaries (16\%), and FWCs (15\%).

Figure 3: Cadre-wise urban-rural distribution of static public facilities in Multan, 2010

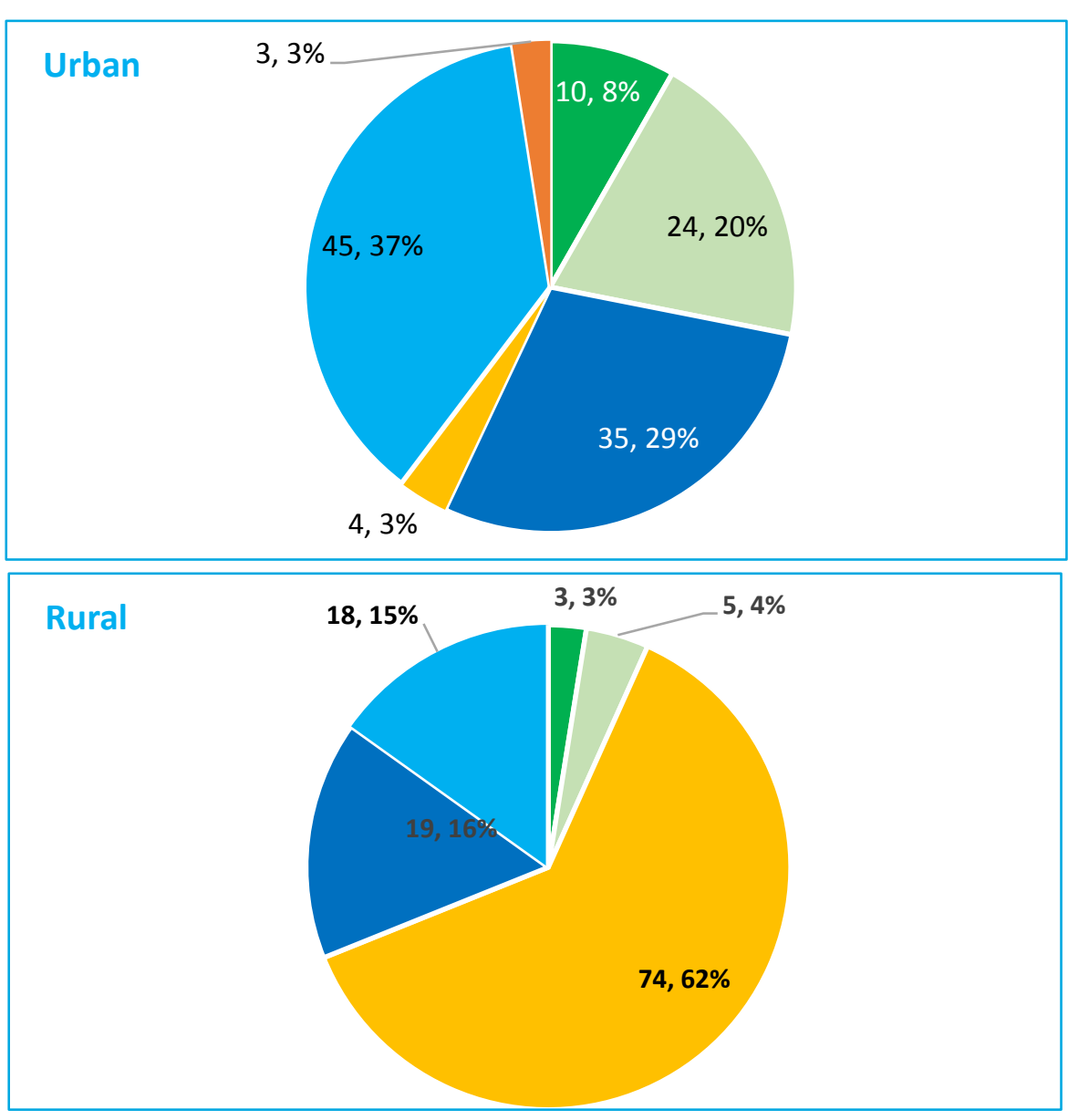

- Public Hospitals

\section{Distribution of Private Facilities by Cadre}

Figure 4 shows the distribution of private facilities in urban and rural areas of Multan. In urban areas, homeopath/hakeem clinics are present in the largest number (52\%), followed by dispenser clinics (18\%), and clinics of male doctors $(16 \%)$. In rural areas, again homeopath/hakeem clinics are most numerous (50\%), followed by dispenser clinics (41\%), and clinics of male doctors (4\%).

Figure 4: Cadre-wise urban-rural distribution of private facilities in Multan, 2010

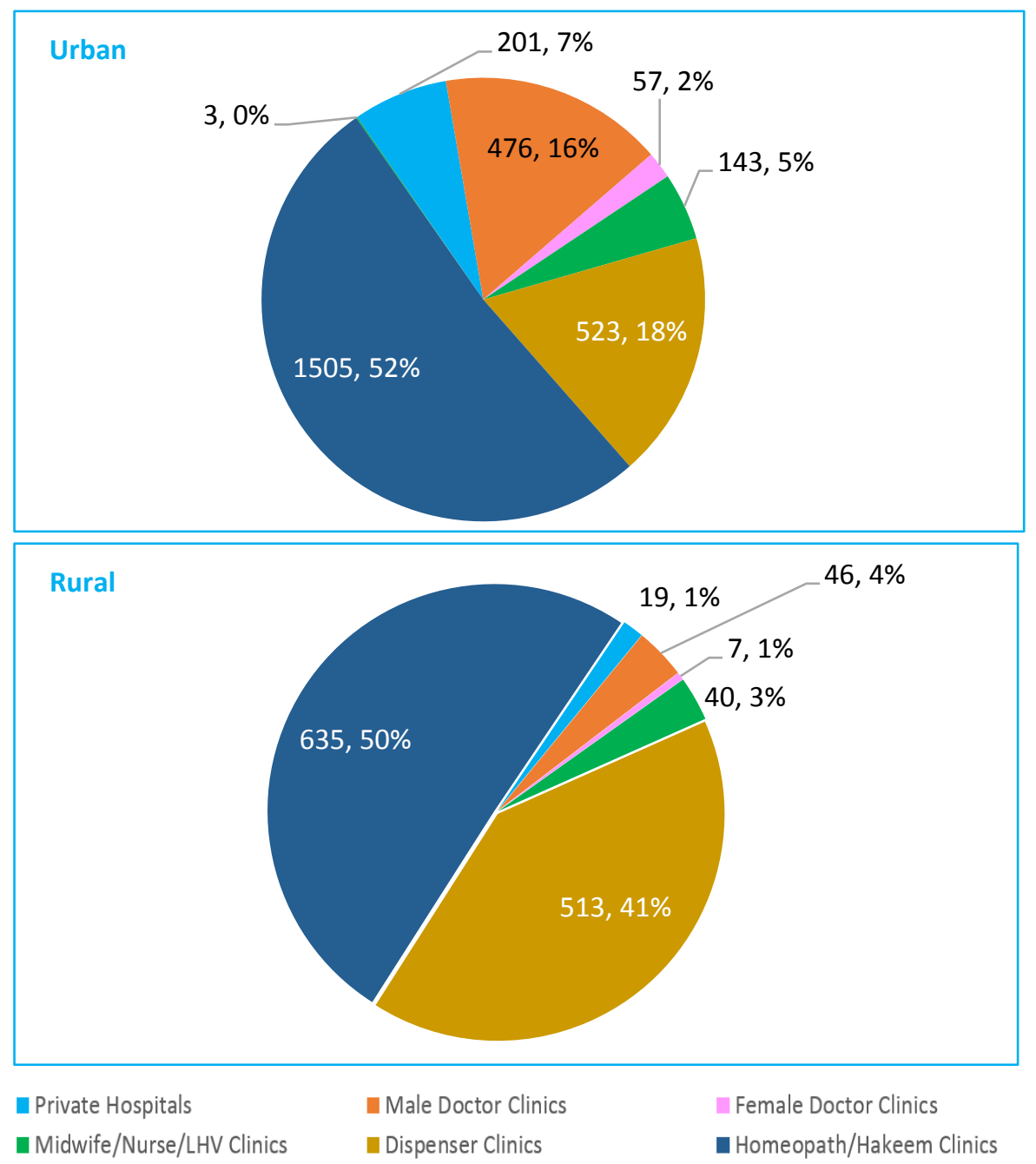




\section{Provision of Specific Family Planning Methods by Sector}

Table 3 shows the proportion of facilities in different sectors providing specific family planning methods in urban and rural areas. DoH facilities are providing most methods. PWD facilities are fully providing most methods. LHWs are almost fully providing condoms, pills, and the second/subsequent doses of injectables. Notably, this cadre has a huge potential for providing the first dose of injectables and emergency contraceptive pills (ECPs) as well.

Private facilities are present in huge numbers, and a good proportion is providing some family planning method in both urban and rural areas.

Table 3: Provision of specific family planning methods in Multan by sector, $\%, 2010$

\begin{tabular}{|c|c|c|c|c|c|c|c|c|c|c|c|c|c|c|c|c|c|c|}
\hline \multirow[b]{2}{*}{ Sector } & \multicolumn{2}{|c|}{ Condom } & \multicolumn{2}{|c|}{ OCP } & \multicolumn{2}{|c|}{ Injectables } & \multicolumn{2}{|c|}{ IUDs } & \multicolumn{2}{|c|}{ ECPs } & \multicolumn{2}{|c|}{ Implants } & \multicolumn{2}{|c|}{$\begin{array}{c}\text { Female } \\
\text { Sterilization }\end{array}$} & \multicolumn{2}{|c|}{$\begin{array}{c}\text { Male } \\
\text { Sterilization }\end{array}$} & \multicolumn{2}{|c|}{$\begin{array}{c}\text { Number of } \\
\text { Facilities }\end{array}$} \\
\hline & U & $\mathrm{R}$ & U & $\mathrm{R}$ & U & $\mathrm{R}$ & $\mathrm{U}$ & $\mathrm{R}$ & $U$ & $\mathrm{R}$ & U & $\mathrm{R}$ & $\mathrm{U}$ & $\mathrm{R}$ & U & $\mathrm{R}$ & $U$ & $\mathrm{R}$ \\
\hline $\mathrm{DoH}$ & 81 & 19 & 80 & 20 & 83 & 17 & 79 & 21 & 86 & 14 & 0 & 0 & 57 & 43 & 60 & 40 & 69 & 27 \\
\hline PPHI/PRSP & 0 & 100 & 0 & 100 & 0 & 100 & 0 & 100 & 0 & 0 & 0 & 0 & 0 & 100 & 0 & 0 & 0 & 74 \\
\hline PWD & 74 & 26 & 74 & 26 & 74 & 26 & 75 & 25 & 100 & 0 & 0 & 0 & 100 & 0 & 0 & 0 & 52 & 18 \\
\hline LHWs & 100 & 100 & 100 & 100 & 100 & 100 & NA & NA & NA & NA & NA & NA & NA & NA & NA & NA & 844 & 899 \\
\hline Private & 77 & 23 & 79 & 21 & 79 & 21 & 86 & 14 & 93 & 7 & 0 & 0 & 90 & 10 & 88 & 13 & 2905 & 1260 \\
\hline
\end{tabular}

U: Urban, R: Rural, OCP: oral contraceptive pill; ECP: Emergency contraceptive pills, IUD: Intrauterine Device

NA: Not applicable 


\section{Presence and Provision of FP Services/Products: A Comparison}

Figures 5 and 6 present pairs of maps showing the presence of public health facilities and private health facilities, respectively, and actual provision of family planning services/products by each category. Figure 5 shows that, collectively, 93 percent of the 240 public health facilities present are providing family planning services.

Figure 5: Proportion of public static health facilities providing at least one FP service, 2010
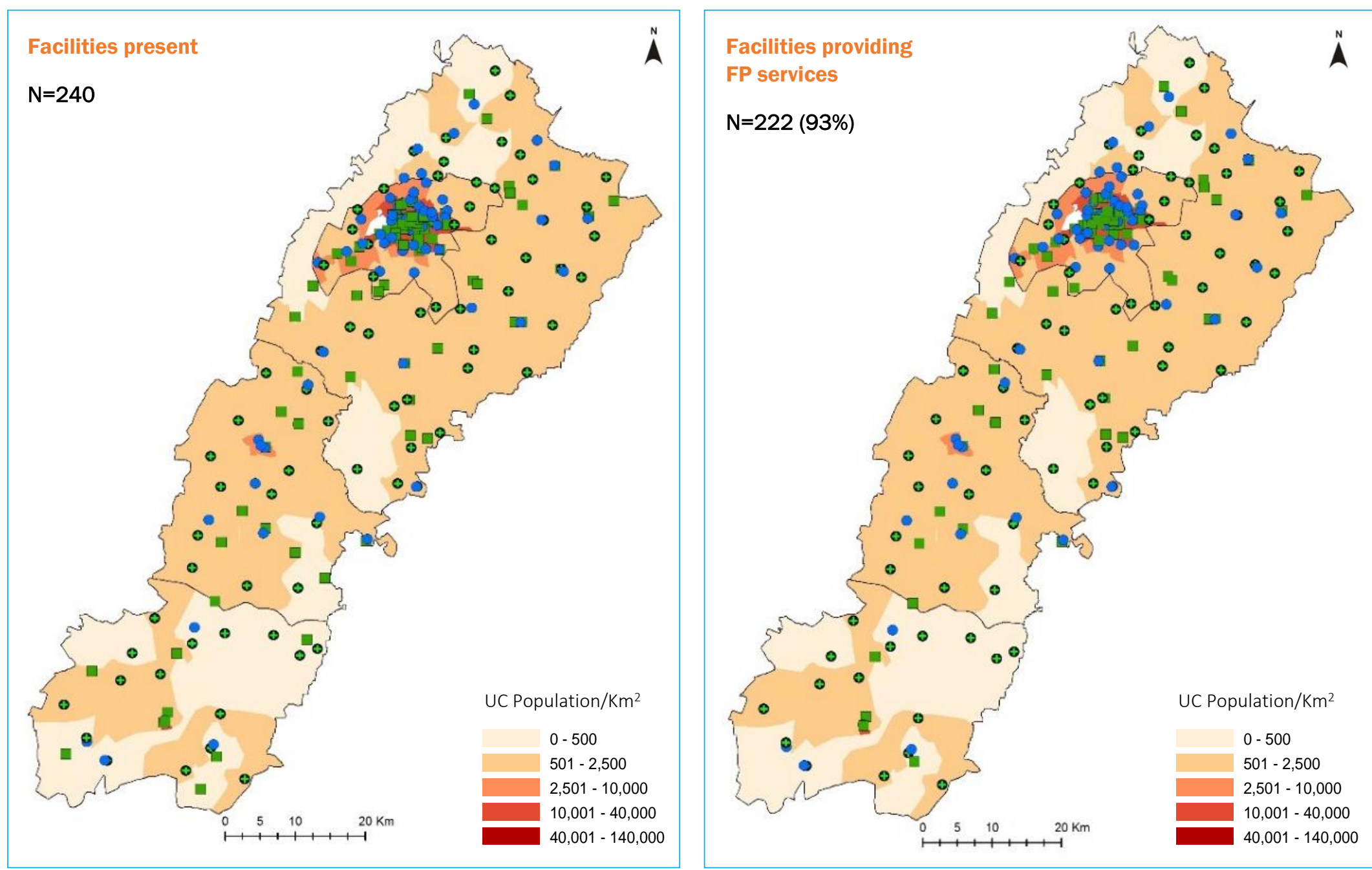

Department of Health (DoH)

- Punjab Rural Support Programme (PRSP)

- Population Welfare Department (PWD) 


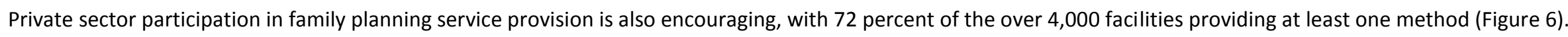

Figure 6: Proportion of private static health facilities providing at least one FP service, 2010

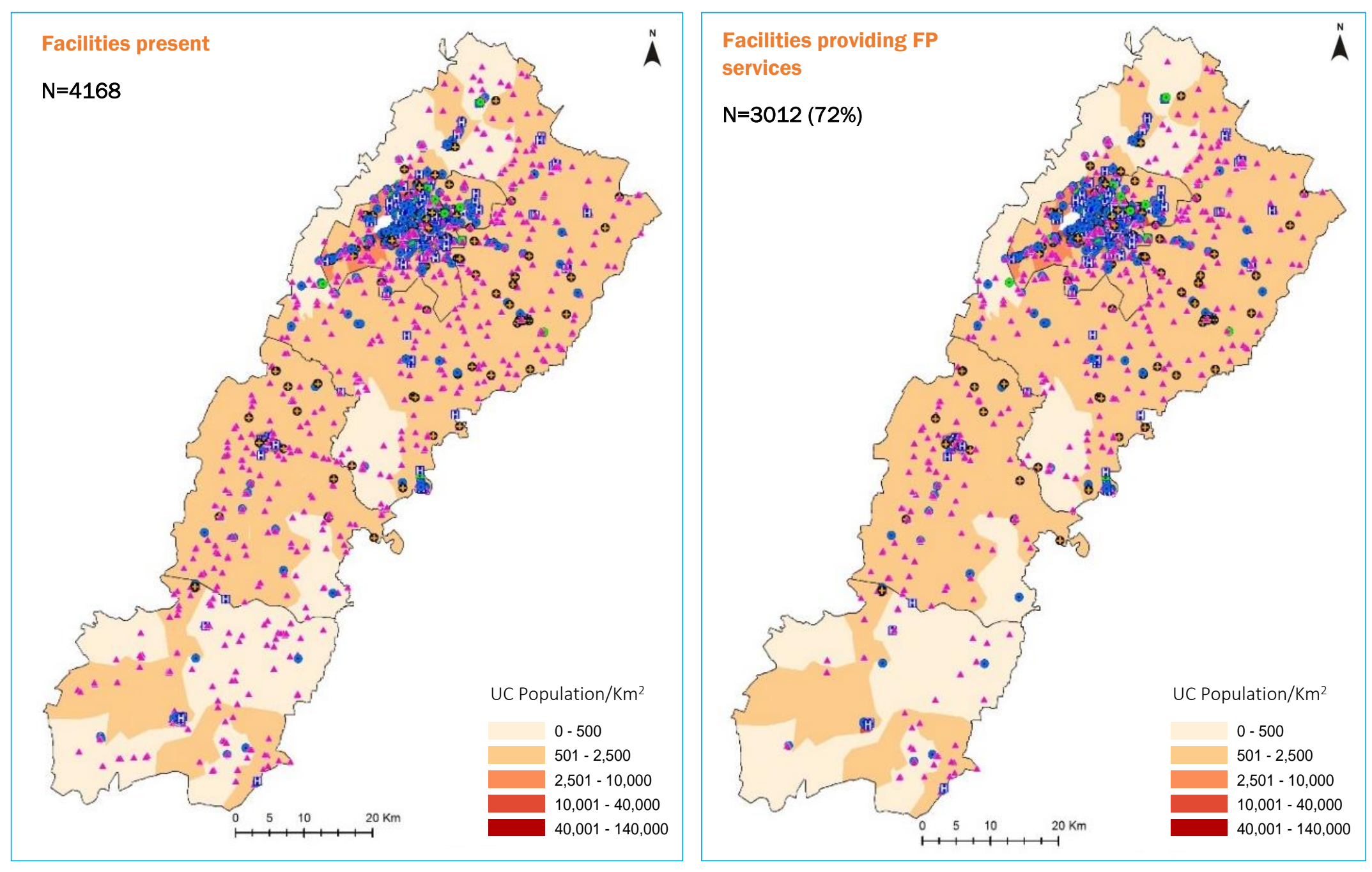

(1) Private Hospitals

- Male Doctor Clinics

- LHV/Nurse/Midwife Clinics

- Female Doctor Clinics

4 Dispenser Clinics

$\oplus \quad$ Homeopath/Hakeem Clinics 


\section{Consumer Perspectives on Barriers to Use of Family Planning}

During the landscape assessment of family planning, qualitative interviews were conducted with men and women for their views on family planning at two urban sites in Multan. In total, 29 in-depth interviews were conducted (with 23 women and 6 men), while 3 focus group discussions were also conducted with men and women. A total of 56 men and women participated in these interactions from this study district.

Three main issues emerged as strong barriers in adoption of family planning, including lack of family planning information and services for men; cost of use, for poor couples; and poor quality of services at public health facilities.

\section{Lack of information among men}

- Men have limited opportunities and venues to discuss family planning; their strong concerns are that they do not know where to go for family planning services or who to talk to for information.

"We gather on festivals such as Eid or at marriage ceremonies, but generally men do no talk about family planning. When close friends sit together, they have general discussions; sometimes, they might talk about family planning." Male, Multan city

"Men face more problems in getting information about family planning than women." Male, Multan city

- Men feel embarrassment in purchasing condoms from shops.

"I'm not bold enough to buy condoms from shops. I went to the shop of a man I knew three, four times and turned back because I lost the nerve. One time I went and there was small boy in the shop. I just asked him for a condom and he gave it to me in a bag....but I felt much embarrassed to try that again." Male, Multan city

"Once I saw a lady purchase contraceptive pills at a pharmacy, and I thought: She is a woman and she's buying pills, and I'm a man, and still can't buy condoms with any confidence." Male, Multan city
- Due to lack of information, some men don't even know how to use condoms.

"I did not know what a condom was. I saw it in a shop when people were buying it. I asked them about its use and told them that I have small children and I want to use it. They guided me and informed me that its price is just 20 rupees and you can use it when you want. I purchased it but still did not use it because I did not know how. It seemed like a dirty thing to me." Male, Multan city

Poor quality of services at public facilities, combined with high cost of services at private facilities

- Women mostly prefer to get family planning services and contraceptives from private providers, who they trust more, due to the poor quality of services at public facilities.

"The facilities of government hospitals are not good. I do not trust them. The hospital here does not have a good standard." Female, Multan city

- At times, they prefer their family's general service provider, even if she is not a doctor, or the provider who conducts their deliveries.

- Sometimes they even procure injectables or IUDs from a public or NGO facility, where they are cheaper, and have them dispensed by their trusted private service provider.

"Government facilities provide free of cost services, but I don't have any problem paying the fees. I trust my private family doctor, so I had the IUD inserted at her facility and she charged me 500 rupees." Female, Multan city

- However, cost is a barrier for middle-income and poor couples, who also prefer private care due to better quality. 
- Middle income women manage with difficulty.

"She charged me 2,500 rupees for the copper T. She said it was of good quality and therefore expensive. It was hard to arrange, because my husband is a rickshaw driver-only one bread-earner and many mouths to feed-but I managed by saving gradually." Female, Multan city

- Poor women cannot pay for commercial services, but wait for camps arranged by NGOs, which they prefer to public services.

"I had already heard about implants because my sister-in-law is using it, but I could not afford the cost of a private doctor. I thought I would use it when it became available for free. Then a team came (NGO), and I asked them whether it was free, and they said, 'Yes, it is almost free! We will only charge you 200 rupees, and pick and drop you for the procedure.' This is how I decided to get an implant from their hospital." Female, Multan city
- Management of the side effects is an additional financial burden that is hard to bear.

"I spent 800 rupees for removal of the implant. Treatment of side effects was too costly for me. We are poor people; we can't afford the expense of medicines and travel. The insertion was free but the cost of treating side effects later was difficult to manage." Female, Multan city 


\section{District specific Donors, Projects and Implementing partners}

\begin{tabular}{|c|c|c|}
\hline Donor & Program/ Project Title & Implementing Partner \\
\hline DFID & Delivering Reproductive Health Results (DRHR), 2012-2017 & $\begin{array}{l}\text { Population Services International (PSI)/ Greenstar Social } \\
\text { Marketing (GSM) } \\
\text { Marie Stopes International: Reproductive Health Franchise } \\
\text { DKT International/Pakistan }\end{array}$ \\
\hline \multirow{2}{*}{$\begin{array}{l}\text { Bill and Melinda } \\
\text { Gates Foundation }\end{array}$} & $\begin{array}{l}\text { Building Blocks for Family Planning in Pakistan - Developing a Costed } \\
\text { Implementation Plan for Sindh and Punjab, 2013-2015 }\end{array}$ & Pathfinder International \\
\hline & Landscape Analysis of Family Planning in Pakistan, 2015-2016 & Population Council \\
\hline \multirow{3}{*}{$\begin{array}{l}\text { The David \& Lucile } \\
\text { Packard } \\
\text { Foundation }\end{array}$} & $\begin{array}{l}\text { Increasing Access and Use of Contraceptives in Punjab/Sindh: Keeping } \\
\text { Momentum \& Innovating for Success, 2012-2015 }\end{array}$ & DKT Inc. \\
\hline & $\begin{array}{l}\text { Achieving MDG5 - Continuing Momentum, Building Champions, 2012- } \\
2015\end{array}$ & Shirkat Gah Women Resource Centre \\
\hline & $\begin{array}{l}\text { Strengthening and Sustaining Postpartum Family Planning in Pakistan, } \\
\text { 2013-2015 }\end{array}$ & JHU - JHPIEGO \\
\hline USAID & DELIVER Project, 2008-2016 & $\begin{array}{l}\text { The Planning Commission of Pakistan, The Ministry of Health } \\
\text { (MOH), Provincial and Regional Departments of Health and } \\
\text { Population, UNFPA, and NGOs }\end{array}$ \\
\hline \multirow[b]{2}{*}{ UNFPA } & $\begin{array}{l}\text { Capacity Building of Female Service Providers Enhanced in Family } \\
\text { Planning, 2014-2017 }\end{array}$ & $\begin{array}{l}\text { Population Welfare Departments } \\
\text { MNCH Programs } \\
\text { LHWs Program }\end{array}$ \\
\hline & $\begin{array}{l}\text { Advocacy for Universal Access to Reproductive Health and to Integrate } \\
\text { in Provincial Health Policies, Plans and Budgetary Frameworks, 2012- } \\
2017\end{array}$ & $\begin{array}{l}\text { Population Welfare Departments } \\
\text { Population Council } \\
\text { Pathfinder } \\
\text { Ministry of National Health Services, Regulations and } \\
\text { Coordination }\end{array}$ \\
\hline WHO & $\begin{array}{l}\text { Providing Technical Assistance to the Country for the Development of a } \\
\text { Unified Care Providers Manual on FP based on the WHO Handbook on } \\
\text { FP }\end{array}$ & $\begin{array}{l}\text { Ministry of National Health Services Coordination and } \\
\text { Regulation } \\
\text { MNCH programs } \\
\text { UNFPA, Population Council, GIZ, USAID etc. }\end{array}$ \\
\hline $\begin{array}{l}\text { Large Anonymous } \\
\text { Donor (LAD) }\end{array}$ & $\begin{array}{l}\text { Increasing Access to and Use of Long Term Methods of FP and PAC } \\
\text { Services in Pakistan, 2014-16 }\end{array}$ & Greenstar Social Marketing \\
\hline
\end{tabular}

